Charlotte Haug (f. 1959) er dr.med. og har en mastergrad i helsetjenesteforskning fra Stanford University. Hun har vært sjefredaktør i Tidsskriftet siden 2002

Foto: Einar Nilsen

Vi stikker hodet i sanden hvis vi (igjen) tror

at patogene virus og bakterier kan isoleres til land og befolkninger langt borte

\title{
Ebola - når vil vi lære?
}

«For dem som sier det er håpløst, er dette en motgift - ebola kan kontrolleres,» sa Thomas Frieden, direktør for det amerikanske Centers for Disease Control and Prevention (CDC) i slutten av september. Nigerias helseminister hadde kunngjort at ebolautbruddet lot til å være over der. 20. juli 2014 hadde en akutt syk passasjer landet på den internasjonale flyplassen i Lagos, en by med over 20 millioner innbyggere. Han rakk å eksponere om lag 70 personer på flyplassen og sykehuset før det ble klart at han var smittet. Helsemyndighetene i Nigeria etablerte umiddelbart et sentralt nødhjelpssenter. Indekspasienten døde 25. juli. To måneder senere var 19 pasienter blitt smittet - åtte av dem var døde, de andre 11 var utskrevet. Nær 900 kontakter var identifisert og fulgt opp. Alle var erklært utenfor fare. Ingen nye tilfeller var rapportert etter 31 . august (1).

Dagen etter den gledelige nyheten fra Nigeria meldte CDC om det første tilfellet av ebola i statene (2). En mann hadde reist symptomfri fra Liberia og var blitt syk fire dager etter ankomst i USA. Han oppsøkte sykehus, fortalte at han nettopp var kommet fra Liberia, men ble sendt hjem med antibiotika fordi helsepersonellet ikke koblet symptomene og hvor han hadde vært. Etter to dager ble han alvorlig syk med oppkast og diaré og ble hentet i ambulanse. Kontakter ble identifisert, men flere feil ble gjort. Pasientens samboer og tre andre som hadde vært i leiligheten sammen med ham, fikk portforbud. Væpnet vakt tok oppstilling utenfor. Men ingen ville fjerne håndklær, sengetøy og madrasser som pasienten hadde brukt mens han var syk, og ingen ville gjøre rent! Først etter noen dager fikk de flytte til en leilighet en privatperson hadde stilt til disposisjon. I skrivende stund er pasientens tilstand karakterisert som kritisk. Ingen av de andre har så langt fått symptomer, men det vil være ren flaks om man unngår flere smittetilfeller.

Det er altså ikke bare et spørsmål om ressurser, men om organisering av ressursene. For vi i vet godt hvordan ebolavirusutbrudd skal håndteres. I 2000-01 registrerte man totalt 425 tilfeller og 224 dødsfall knyttet til viral hemoragisk feber i Uganda, det største ebolautbruddet i verden til da (3). Til tross for mange vansker fikk koordinert innsats fra nasjonale og internasjoanle myndigheter og organisasjoner utbruddet under kontroll. Også i 2007 og 2011 ble ebolautbrudd stoppet effektivt i Uganda (4).

«Som hivepidemien selvsagt nå må ha lært oss, finnes det for infeksjonssykdommer ingen steder i verden som er langt av sted og ingen vi ikke er knyttet sammen med.» Dette skrev en arbeidsgruppe i forordet til rapporten Emerging infections: microbial threats to health in the United States i 1992 (5). De erkjente at man i årene før hivepidemien oppsto hadde undervurdert infeksjonssykdommenes potensial til igjen å bli et alvorlig medisinsk problem. Man trodde man kunne holde infeksjoner under kontroll med antibiotika og vaksiner og «glemte» de tradisjonelle virkemidlene som forebygging av spredning og smittevern. Hivepidemien fikk derfor - tragisk nok en utbredelse og et omfang som ble langt større enn nødvendig.

Rapporten fikk store konsekvenser, blant annet begynte WHO i 1994 igjen for alvor å konsentrere seg om smittsomme sykdommer - etter at organisasjonen hadde nedprioritert dette arbeidet siden 1970-årene (6). Også de medisinske tidsskriftene engasjerte seg. I januar 1996 publiserte 36 tidsskrifter i 21 land 242 ulike artikler om temaet (7), og i 2000 etablerte WHO The Global Outbreak Alert and Response Network (GOARN), som skulle «sørge for et operativt rammeverk som kobler ekspertise og kompetanse slik at det internasjonale samfunn kontinuerlig er på vakt overfor truende utbrudd og er klare til å respondere» (8).

Utbruddet av viral hemoragisk feber i Uganda i 2000-01 var første gang koordineringen ble håndtert av dette nettverket. Det var vellykket (3). Så hva har skjedd etter den tid? Hvorfor reagerte ikke WHO eller verden for øvrig på ebolautbruddet som startet $\mathrm{i}$ Vest-Afrika i desember 2013 på et tidspunkt da det var lite og håndterlig? Hjelpeorganisasjoner som Leger Uten Grenser forsøkte i flere måneder å slå alarm, men først da misjonærer og hjelpearbeidere fra Europa og USA ble smittet, begynte alarmklokkene å ringe for alvor.

Vi stikker hodet i sanden hvis vi (igjen) tror at patogene virus og bakterier kan isoleres til land og befolkninger langt borte. Selvsagt er vi langt bedre rustet til å takle en epidemi i privilegerte Norge enn i Liberia. Men virus og bakterier kjenner ingen landegrenser. Eller - som helseminster Onyebuchi Chukwu i Nigeria advarte da gladnyheten kom om at ebolautbruddet var under kontroll i hans hjemland: « $\AA$ kunngjøre at et land er ebolafritt er bare teoretisk. Så lenge det er ett eneste tilfelle av ebola i noen del av verden, er alle land utsatt.»

\section{Litteratur}

1. Shuaib F, Gunnala R, Musa EO et al. Ebola virus disease outbreak - Nigeria, july-september 2014. MMWR Morb Mortal Wkly Rep 2014; 63: 867-72.

2. CDC and Texas Health Department confirm first Ebola case diagnosed in the U.S. www.cdc.gov/media/releases/2014/s930-ebola-confirmed-case.html (6.10.2014).

3. Lamunu M, Lutwama JJ, Kamugisha J et al. Containing a haemorrhagic fever epidemic: the Ebola experience in Uganda (October 2000-January 2001). Int J Infect Dis 2004; 8: 27-37.

4. Shoemaker T, MacNeil A, Balinandi S et al. Reemerging Sudan Ebola virus disease in Uganda, 2011. Emerg Infect Dis 2012; 18: 1480-3.

5. Emerging infections: Microbial threats to health in the United States. Washing ton D.C.: National Academy Press, 1992.

6. Emerging infectious diseases: memorandum from a WHO meeting. Bull World Health Organ 1994: 72: 845-50.

7. Haug C. Leger i alle land - foren dere! Tidsskr Nor Lægeforen 1996; 116: 353-4.

8. Global Outbreak Alert \& Response Network. www.who.int/csr/outbreaknetwork/ en/ (6.10.2014). 